\title{
THE DEVELOPMENT OF CAI BASED ANDROID IN SOLAR SYSTEM AND UNIVERSE TOPIC FOR TENTH-GRADE
}

\author{
Marwiyah $^{1^{*}}$, Rusijono ${ }^{1}$, Fajar Arianto ${ }^{1}$ \\ ${ }^{1}$ Master Program of Educational Technology, State University of Surabaya, Indonesia \\ *Email : marwiyah.17070905004@mhs.unesa.ac.id
}

Received 21 February 2019/ Revised 8 July 2019/ Accepted 15 July 2019/ Published 1 August 2019

\begin{abstract}
The aim of the research to generate learning media, thus the media development will assist students to understand the content during the learning process. Besides establishing a product, the manual guide was also arranged. The method used was Research and Development (R \& D) model, the validation result of content expert I and II obtain a very good category and media experts I and II also obtain a very good category. The result of individual test is categorized very well with percentage of $91.01 \%$, the result of small group test is categorized very well with percentage of $91.43 \%$, the result of the large group test is categorized very well with percentage of $89.60 \%$. Hence, based on the result of Android-based CAI media development of Geography in solar system and universe topic of tenth-grade in Al-Iftitahiyah High School needs to be developed and utilized as a learning media that could support the teaching and learning process.
\end{abstract}

Keywords: Development, CAI Based on Android, Geography

\section{Introduction}

Technology grows rapidly in modern times, where millennials are significantly dependent to it. In the sense of technology education and learning, technology can be engaged as a learning media for wider information and in the current era of globalization. It is not quite recent that media has become an integral part of the learning process. This can be noticed the media is anything that can be used to deliver messages from sender to recipient, hence media possess capacity in stimulating students' thoughts, feelings, and interests, thusthe learning process occurs. (Sadiman, 2007: 7). The learning process that still only relies on the teacher's ability to explain 
Marwiyah, et al/GEOSI Vol. 4 No. 2 (2019) 63-77

learning contentgenerates impact, such learning process will unlikely to be effective enough to enact thinking patterns of students inunderstanding the contentbetter.

The development of learning equipment in the form of teaching content modelis employedas a reference for educational unit in developing or engaging teaching content which is sustainable, actual, and appropriate manner to the needs and conditions of the education unit concerned. The selection of teaching contents is determined based on difficulty level and depth of the content, the characteristics of the subject matter, the complexity in selecting learning strategies, students character, the conditions of the learning facilities and infrastructure available. This CAI-based development media engages Android within learning process of Geography subject.

Geography is a subject that proposes content in the form of memorization. While the topicis unpopular upon the students, this will encourage students to meet difficulties in receiving the learning content. In Solar System and Universe subject, students encountered complicated issues to recall the names of solar system and universe. Thus, the presence of interesting media is very compulsory and needed to overcome the problems experienced by students and teachers during the learning process.

Learning media has a significant impact in the term of learning process quality and learning outcome. The unecessary media possibly cause the lack of response, motivation, and interest of students toward the subject. Considering these facts, the presence of media that is not suitable over the needs will deliver another issue. In the other hand, a presence of an attractive media could support students to be more enthusiastic and understand the subject matter. Furthermore, there is a study which conducted upon on instructional media utilization in teaching and learning process. Result of the study shows that the process and the learning outcomes of students reveal significant differences between learning without media and learning using media. Therefore, the learning media engagementwithin learning process is highly recommended to enhance the quality of learning (Sudjana and Rivai, 2010: 3). Based on the result of interview and preliminary observation, the issues experienced by students were bored feelings and difficulty to grasp the content delivered to the tenth-grade students of Al-Iftitahiyah Senior High School Batuputih Sumenep.

Android is a software platform as well as an operating system based on the Linux kernel. It is an open source in which accessible to be developed by developers from all over the world. 
Marwiyah, et al/GEOSI Vol. 4 No. 2 (2019) 63-77

Android is used by more than 300 million devices and 850 thousand devices are activated every day (Bhardwaj et al., 2013). Android market share in the whole world currently hits $73.05 \%$, with its closest competitor being iOS with $19.99 \%$ ("Mobile operation", 2017). In Indonesia, Android tops the highest market share of $83.99 \%$ in July 2017, far exceeding iOS which only reached 3.09\% ("Market share held", 2017). Android application is very massive on daily life. It also can be used by teachers to develop learning that is supported by smart phones or other devices based on Android. Then, the development of CAI based on Android is in accordance to the development of education currently. The research of media CAI based android development modelengages Research and Development model (R \& D) by Sugiyono (2015).

\section{The Methods}

According to the issue background mentioned above, it is necessary to develop CAI media based Android onGeography subject focusing on Solar System and Universe topic of tenth-grade students in Al-Iftitahiyah High School BatuputihSumenep. This research is also based on research result conducted by Rika Dian Kurniawan, (2015: 6) which provides suggestions for the development of CAI media. It suggests further action to develop media in other subjects and other subject matter, thereby the learning media is becoming more varied.

The relevance of this research title with the concept of Educational Technology definition could be observed from the Association for Educational Communications and Technology (AECT) in 2008 as follows:

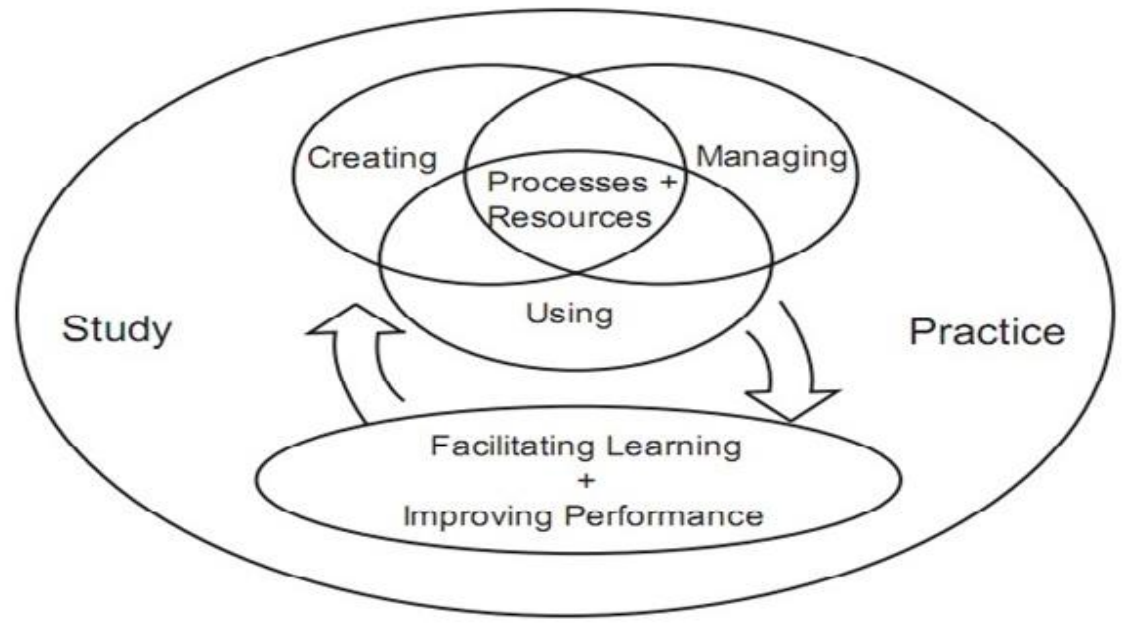

Figure 1. Educational Technology Domain (Januszweski and Molenda, 2008: 5) 
Marwiyah, et al/GEOSI Vol. 4 No. 2 (2019) 63-77

Based on learning technology domain,according to Molenda (2008) dividing Education Technology area into three parts, namely; creation/creating, utilization, and managing.Within the development of CAI media, if it is related to the direction of development,then it is included the Creation/creating scope. The purpose of this research is to generate a product in the form of CAI to improvelearning content of Solar System and Universe topicfor tenth-grade class Geography subject. The object of this research is Al-Iftitahiyah High School students Batuputih Sumenep.

Basically, there are three main steps of establishingthe tutorial model, as follows: (1) formulating the Interactive Multimedia.Tutorial design model program by analyzing the curriculum and competency, hence it produces media program outline (BGPM) (2) arranging flowchart learning program tutorial model, interactive multimedia tutorial, storyboard model, and (3) Using computer device as the main equipment with appropriate software and hardware in programming (Susilana and Riyana, 2007: 147). For the $1^{\text {st }}$ stage and $2^{\text {nd }}$ stage have already explained earlier. The characteristic of the tutorial model is clearlyillustratedin the flowchart as follows:

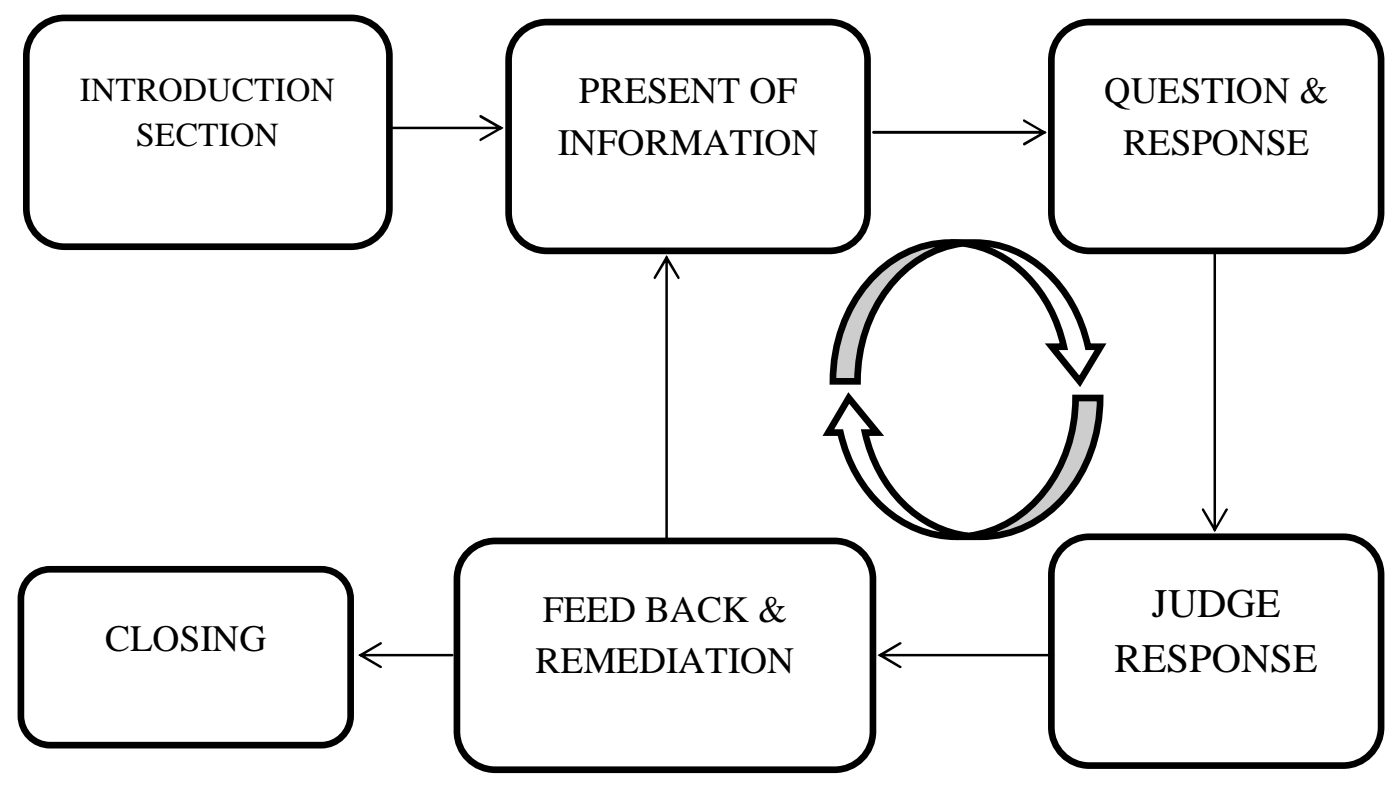

Figure 2. Flowchart Tutorial Model (Susilana and Riyana, 2007:148)

The flowchart illustrates that tutorial model is divided into 6 parts, namely; the introduction part, the information presentation section, the presentation of questions and program 
Marwiyah, et al/GEOSI Vol. 4 No. 2 (2019) 63-77

responses, responses consideration, the information section, feedback and responses. The improvements will keep performing as long as students have not succeeded, and if it has succeeded, it will be completed by the closing section.

Presentation of development activities has been adapted to the development procedures for the modification of Research and Development (R \& D) according to Sugiyono (2015). The steps description for CAI-based Android media developmentare explained below:

1) Potential Problems

The initial stage of developing the Android-based CAI media conducted by direct observation to Al-Iftitahiyyah High School, BatuputihSumenep. Based on observations performed at tenth-grade class, there are some factualconditions of learning that can be identified, which are: the unavailability of instructional media except textbooks and classical method learning used during the learning process. Thereby, students experience difficulties within independent learning process.

2) Data Collection

After the potential and problems were being identified, it is required to collect various data that can be engaged as content for planning certain product that is expected to cope with the problem. In order to collect the initial data such as; students characteristics, media and the learning methods that are being used, students difficulties in the learning process. In addition, interviews were also addressed to content experts and media experts to obtain validity of thecontent used in the media, obtain improvements and feasibility of media that would be applied in the learning process.

3) Product Design

Before arranging CAI production based on android, it is notable to establish a program script and storyboard (Susilana and Riyana, 2007: 147). Storyboard testing is a benchmark for the success of making a product in the form of a prototype, then a media is suitable for learning. Trials were conducted by discussingwithcontent experts regarding thecontent to be presented in the Android-based CAI program,researcher also discussed with media experts relating the media to be generated

Referring to Sugiyono (2009: 298) there are ten steps of research and development, as follows: (1) potential and problem (2) data collection (3) design product (4) design validation (5) 
Marwiyah, et al/GEOSI Vol. 4 No. 2 (2019) 63-77

design revision (6) trial product (7) product revision (8) trial usage (9) product revision (10) and mass production. The research steps are shown in the following figure:

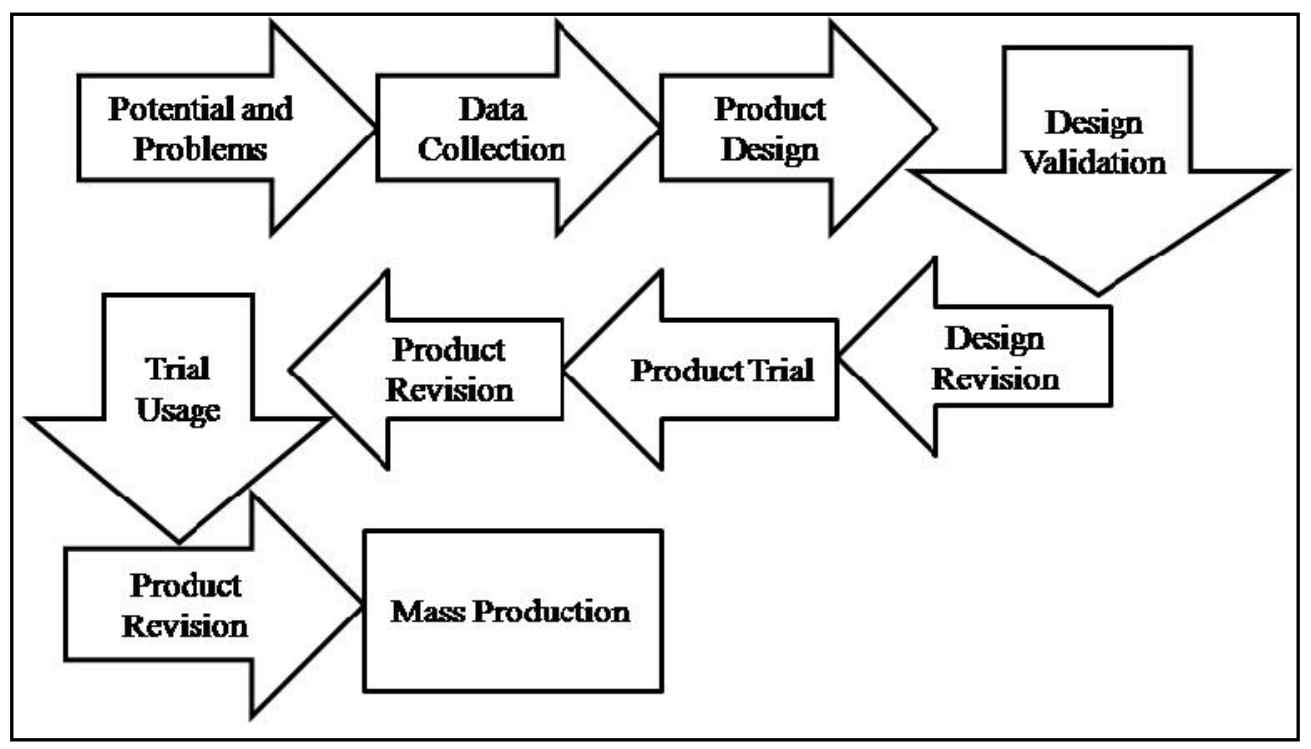

Figure 3. Research and Development Procedure (Sugiyono, 2015:409)

In the development of CAI media, it employs the procedures and R \& D steps. It includes several development-based stages.

1) Potential and problems: at this stage the developer observes and identifies the problem. Based oninterviewresults, most students did not understand the content properly.

2) Data collection: data obtained from interviews, student learning outcomes, syllabus and lesson plan of Geography subject, the Solar System and the Universe topic.

3) Product design: In this step, developer designs the CAI media as suitable as possible. The product design produced is in the form of a story board, which is a description of the CAI media that will be developed. After story board was finished, then examining the media with the experts to do a validation upon design made by the developer.

4) Design Validation: the result of the development design in the form of a CAI learning media draft, consulted with content experts and media experts. 
Marwiyah, et al/GEOSI Vol. 4 No. 2 (2019) 63-77

5) Improved Design: the revised result of the CAI media in the form of product drafts wasimprovedin accordance to the revised version referring to the media experts and contentexperts suggestion.

6) Product testing: CAI media was tested associated to the purpose and the chosen target.

7) Product Revision: after being tested in small groups to determine the weaknesses and shortcomings of the media. Therefore, the result of the CAI media draft was revised by several experts such as media experts and content experts.

8) Trial Use: following the revision, the product wasexamined in a broad scope or in large groups.

9) Product revision: after being tested on large groups. The CAI media was revised again to obtain eligibility to improve media development.

10) Making Mass Products: after the revised CAI media product was considered feasible and effective. Then, it finally can be produced to assist and facilitate the learning process in science subjects of structure and function of plant tissues content.

The development test should be carried out in a complete and comprehensive way that can be performed in three stages of examination/testing, which are individual testing, small group testing and field testing. Those stages are expected to gain the best results that related to the factual conditions (Rusijono and Mustaji, 2008: 44).

Data collection instrument in this study performs interviews for content experts and media experts, the type of interview used in this study is structured interviews referring to Sugiyono(2010: 194-197). Data collection instrument works to determine students' assessment of the CAI media based Android using closed anarchy Arikunto (2006: 151).

Descriptive analysis is obtained from assessment questionnaire result through individual trials (content experts, media experts, and students), small group trials and large groups and interviews with content experts and media experts. This descriptive percentage is processed by dividing frequency with the number of respondents and multiplied by 100 percent, asDikjanaSudjana explained (2001: 129) is as follows:

$$
\mathrm{P}=\frac{f}{N} \mathrm{X} 100 \%
$$


Marwiyah, et al/GEOSI Vol. 4 No. 2 (2019) 63-77

Details of information:

P: Percentage result

$\mathrm{F}$ : a frequency that the percentage is being searched

$\mathrm{N}$ : Number of respondents/individuals

After data is being calculated by the formula above, then it could be analyzed by dividing the frequency of answers for each alternative chosen by the respondent with $100 \%$ and the next stage will be discussed with the assessment criteria. Guidelines for interpreting the results of analysis are decided.

Table 1. Assessment Criteria

\begin{tabular}{ccl}
\hline Range of Percentage & Criteria & \multicolumn{1}{c}{ Information } \\
\hline $76 \%-100 \%$ & Very good & Ready to use in PBM (without revision) \\
$56 \%-75 \%$ & Pretty good & Ready to use in PBM (without revision) \\
$40 \%-55 \%$ & Deficient & Revision \\
$<40 \%$ & Not good & Revision \\
\hline
\end{tabular}

If the calculation result is between $76 \%-100 \%$, then this media is considered to be appropriate for the teaching and learning process which does not require to be revised, but if the calculation value is between, $0 \%-56 \%$ then the media is considered less feasible and revisions are absolutely needed.

\section{Results and Discussion}

3.1 Validation of CAI Media Design Based Android in Solar System and Universe Topic

During development phase of the Android-based CAI program, a valid test will be conducted for content experts and media experts. Within the procedure for developing the Android-based CAI program, it is performed in three steps, i.e. analysis, Android-based CAI program design and Android-based CAI program development.

a. The step of analysis consists of 6 (six) stages; (1) conducting interviews with the institution; (2) identifying student needs, (3) identifying student characteristics; (4) identifying CAI-based Android media development goals; (5) determine and collect resources; and (6) conduct an evaluation and revision of the analysis that has been carried out. 
Marwiyah, et al/GEOSI Vol. 4 No. 2 (2019) 63-77

b. The design step consists of 3 (three) stages; (1) designing learning contents using CAI media based on Android; (2) arranging design in the form of flowcharts and storyboards as narrative content that will be used as guidelines in developing CAI-based Android media; and (3) conducting an evaluation and revision of the analysis that has been held.

c. The development phase consists of 2 (two) stages; (1) developing CAI-based Android media by using Adobe Flash CS6 based on the flowcharts that have been made; (2) and perform evaluations and revisions.

In this stage of developing the CAI-based Android media will be tested towards 2 (two) content experts and 2 (two) media experts. As for the testing phase of the development of Android-based CAI media, this was completed through three stages of testing, i.e. individual tests consisting of 3 (three) students, small group trials consisting of 10 (ten) students, and usage trials consisting of 26 (twenty six) students.

During the testing stage, content experts and media experts 1 and 2 who will asses attractiveness aspect, which includes the display of CAI-based media on Android, understandingaspect which includes content descriptions and content evaluations, credibility aspect which includes answer keys, technical standards which includes grammar and layout.The review result can be seen in the table below table 2 .

Table 2. Validation of Content Experts and Media Experts

\begin{tabular}{cccc}
\hline No & Validator & Average score & Criteria \\
\hline 1 & Content Expert 1 & $94,31 \%$ & Very Good \\
2 & Content Expert 2 & $92,78 \%$ & Very Good \\
3 & Media Expert 1 & $94,60 \%$ & Very Good \\
4 & Media Expert 2 & $92,49 \%$ & Very Good \\
\hline
\end{tabular}

Source: Data processed (2018)

After collecting the results of the validation from the content experts, there were inputs relating the content in the CAI media based on Android. Then after obtaining the validation results from media experts, there were inputs about the media on the CAI media based on Android. Following the making of CAI-based media production through the revision of content and media experts, the next step was to examine individual products and small group trials. 
Marwiyah, et al/GEOSI Vol. 4 No. 2 (2019) 63-77

At the trial stage on individuals in which will be given to 3 (three) students with a total of 91.18\%, assessment related to attractiveness including the appearance of CAI media based on Android, understanding includes content descriptions, and technical standards including grammar and motivation. The test in this trial was given for students who possess different academic abilities. Students were asked to give comments and fill out the assessment questionnaire. The results of individual trials are presented in table 3.

Table 3. Assessment Distribution of One-To-One Evaluation

\begin{tabular}{|c|c|c|c|c|}
\hline \multirow{2}{*}{ No } & \multirow{2}{*}{ Interval } & \multirow{2}{*}{ Criteria } & \multicolumn{2}{|c|}{$\begin{array}{l}\text { One-To-One } \\
\text { Evaluation Trial }\end{array}$} \\
\hline & & & $\mathrm{F}$ & $100 \%$ \\
\hline 1 & $76 \%-100 \%$ & Very good & 2 & $66,66 \%$ \\
\hline 2 & $56 \%-75 \%$ & Pretty good & 1 & $33,33 \%$ \\
\hline 3 & $40 \%-55 \%$ & Deficient & & \\
\hline 4 & $<40 \%$ & Not good & & \\
\hline \multicolumn{3}{|c|}{ Total } & 3 & $100 \%$ \\
\hline
\end{tabular}

Source: Data processed (2018)

The next stage was a trial of small group evaluations given to10 (ten) students with a total of $91.91 \%$, who will assess the relevance of the appearance of CAI-based media on Android. The understandingincludes content descriptionsand technical standards including grammar and motivation. Each student had a different academic ability in which they were asked to give their responses in the form of comments and filling in the assessment. The results of small group trials are presented in table 4.

Table 4. Assessment Distribution of Small Group Evaluation Trial

\begin{tabular}{ccccc}
\hline & & & \multicolumn{2}{c}{ Small Group Evaluation } \\
No & Interval & Criteria & \multicolumn{2}{c}{ Trial } \\
& & & F & $100 \%$ \\
\hline 1 & $76 \%-100 \%$ & Very good & 9 & $90 \%$ \\
2 & $56 \%-75 \%$ & Adequately good & 1 & $10 \%$ \\
3 & $40 \%-55 \%$ & Deficient & & \\
4 & $<40 \%$ & Not good & 10 & $100 \%$ \\
\multicolumn{2}{c}{ Total } & & &
\end{tabular}

Source: Data processed (2018)

Following testing individual products and small groups, there was revision. It was found that button of the content page in the CAI-Based Android media was not big enough. It made the button less sensitive when students pressedit. Hence, students were still having difficulty 
Marwiyah, et al/GEOSI Vol. 4 No. 2 (2019) 63-77

pressing the next button. The results of the trial were employed to improve the final product before the trial in a large group in the class was performed.

Furthermore, the developer revised the CAI-Based Android media as suggested and conducted a trial. It was given to 26 students in the class, which composed of various levels of ability. As in the previous stage, students were also asked to give their responses in the form of comments and fill out the assessment questionnaire. The total score is $89.95 \%$. The table of evaluation distribution in the trial test can be seen as follows:

Table 5. Assessment Distribution of the Field Test Evaluation Trial

\begin{tabular}{ccccc}
\hline \multirow{2}{*}{ No } & Interval & Criteria & \multicolumn{2}{c}{ Field Evaluation Trial } \\
& & & $\mathrm{F}$ & $100 \%$ \\
\hline 1 & $76 \%-100 \%$ & Very good & 26 & $100 \%$ \\
2 & $56 \%-75 \%$ & Pretty good & & \\
3 & $40 \%-55 \%$ & Deficient & & \\
4 & $<40 \%$ & Not good & 26 & $100 \%$ \\
\hline
\end{tabular}

Source: Data processed (2018)

After the trial use of the large group was completed, the product was revised again to propose the feasibility of learning media utilization and to improve the whole learning media. Furthermore,considering the results of the content and media experts test as well as individual trials, small groups and tests usage, this Android-based CAI media is beneficial to beused as learning media.

3.2 The Effectiveness of CAI Media Utilization Based on Android Solar System Content and the Universe

CAI-based Android media effectiveness in solar system and universe topiccan be seen based on student learning outcomes by comparing the score of the pre-test and post-test. The graph of average results of student learning outcomes before and after using the CAI-based Android media can be observed in the following figure. 
Marwiyah, et al/GEOSI Vol. 4 No. 2 (2019) 63-77

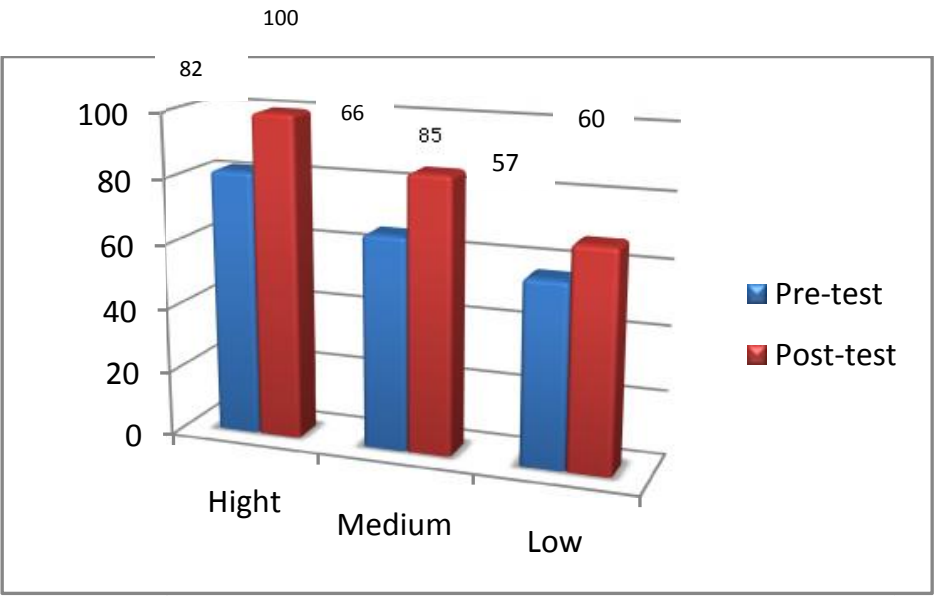

Figure 4. The student`s Average Learning Outcomes

Figure 4 shows that student learning outcomes before and after using the CAI-based Android media have improved; for those who obtain high, middle and low academic achievements. The recapitulation of the comparison of learning outcomes before and after using the CAI-based Android media can be seen in the following figure.

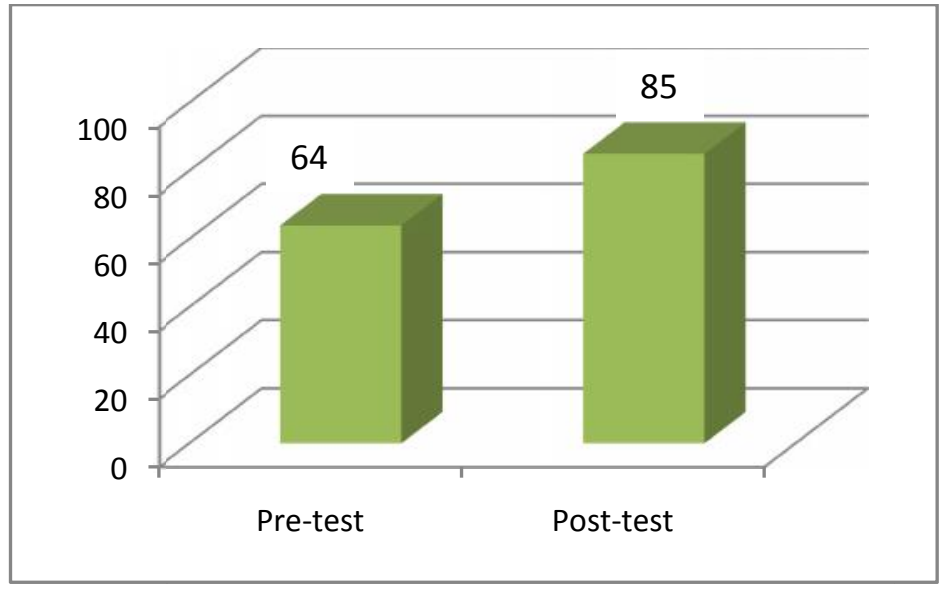

Figure 5. Comparation Recapitulation Graphic of The Student`s Learning Outcomes

Utilization tests that have been carried out in class X of Al-Iftitahiyah High School Batuputih, Sumenep with one group post-test and pre-test method have increased learning outcomes. This is indicated by increasing post-test score compared to the pre-test score. Hence, this Android-based CAI media is effectively beneficial as a learning media for Geography subject of the Solar System and the Universe topic. 
Marwiyah, et al/GEOSI Vol. 4 No. 2 (2019) 63-77

The development of CAI media based android has been proven to be feasible as this learning media suitableupon learning objectives. This mediais also able to provide more positive results for users. Asa research conducted by Edo and Ika (2017: 9) states that Android applications in the form the game is very notable in mathematics if managed properly. This is indicated by the items calculation of user questionnaire number 8 which gains $83 \%$ out of $100 \%$,thatmeans users become more easily understand the contents presented. Likewise, the results of Edwardo's study (2015: 27) conveys thatbased on the results of the post-test and pretest, $\mathrm{t}$ test is larger than $\mathrm{t}$ table which is $9,756>3,334$, thus the animation learning media is feasible and effective. Android-based CAI media language subjects in Java script content in class X SMK 2 Buduran has been developed and it is feasible and effective for use in learning.

Arnita et al (2018: 6) CAI is utilization of computer as a tool in the field of education and teaching that involves teachers and those who are actively playing a role. Learning media in the form of android applications is able to make it easier to operate applications and can be accessed in various places. Suwignyo (2016: 87) states that the results of research and discussion of Computer Assisted Instructions (CAI) learning application in Spreadsheet subjects is able to improve student competency and gives impact towards students activities of Accounting X-2 in the Christian Vocational School of Salatiga.

Setyadi (2016: 52) argues that application of multimedia-based solar system learning media using the CAI (Computer Assisted Instruction) method manages to attract students' interest in learning in the solar system topic. Since, the differences obtain before and after using learning media increase $26 \%$, from $43 \%$ to $69 \%$. Rian et al (2016: 183) based on system testing using questionnaires conducted at Curup 1 High School and MIPA faculty students in Chemistry majors in semester 2 and 4 related to android-based learning. It can be seen that the average of all aspects of assessment are 3.90, 4.13 and 3.89 categorized as "good" category. Thus, the learning media could increase students' motivation in chemistry subjects, especially realting periodic table of elements and the formulation of chemical compounds.

\section{Conclusion}

The results of the overall calculation databased on content experts and media experts shows that the condition of the media is feasible. Thus after performing the sequence of activities in this study, it can be conluded that the (1) Media CAI Based Android which is used in learning 
Marwiyah, et al/GEOSI Vol. 4 No. 2 (2019) 63-77

Geography that focuses on solarsystem and universe topic for tenth-grade studentsis required to be developed and engaged as learning media that could support the teaching and learning process, and (2) CAI Based Android in the scope of Geography, especially in Solar System and Universe topicfor tenth-grade students can accommodate students who are considered slow in embracing lesson, since CAI based on Android is effective in an individual way. Therefore, students donot easily forget and get bored. This happens sinceAndroid-based CAI runsassociates to user instructions.

\section{References}

Arikunto, Suharsimi. (2006). Research From the whole result h Procedure A Practice Approach. Jakarta: PT. RienekaCipta.

Dwinata, R. A. Rusdi, E. Sal, P. Y. (2016). Rancang Abngun Aplikasi Tabel Periodik Unsur Dana Perumusan Senyawa Kimia Dari Unsur Kimia Dasar Berbasis Android. Jurnal Rekursif, 4(2).

Retrieved fromhttps://ejournal.unib.ac.id/index.php/rekursif/article/view/888/1207

Januszewski, A. \& Molenda, M. (2008). Educational Technology. New York: Lawrence Erlbaum Associates.

Kurniawan, Dian. (2015).Android-based Computer Assisted Instruction (Cai) Media Development About Immune Systems in Xi Class Biology in Public High School 1 TarikSidoarjo: http://jurnalmahasiswa.unesa.ac.id/index.php/jmtp/article/view/13450.

Market share held by mobile operating systems in Indonesia from January 2012 to July 2017. (2017).https://www.statista.com/statistics/262205/market-share-held-bymobile-operatingsystems-in-indonesia/.

Rusijono \& Mustaji. (2008). Learning Technology Research. Surabaya: Unesa University Press.

Sadiman et al, (2007). Media Pendidikan. Jakarta: Raja GrafindoPersada.

Setiyadi, Didik. (2016). Media Pembelajaran Untuk Anak Sekolah Dasar Tentang Pengenalan Tata Surya Menggunakan Metode Computer Assisted Intruction (CIA). Information Management For Educators And Professionals, 1(1). Retrieved fromhttp://www.ejournalbinainsani.ac.id/index.php/IMBI/article/view/155/274

Subagyo, Edwardo. (2015). Pengembangan Media CAI Berbasis Android Pada Mata Pembelajaran Bahasa Daerah Materi Aksara Jawa Untuk SiswaKelas X Di SMKN 2 Buduran. Jurnal Mahasiswa Teknologi Pendidikan, 6(3). Retrieved from https://jurnalmahasiswa.unesa.ac.id/index.php/jmtp/article/view/13723/12578

Sudjana,Nana\&Rivai, Drs.Ahmad. (2010). Teaching Technology. Bandung: Sinar Baru Algensindo. 
Marwiyah, et al/GEOSI Vol. 4 No. 2 (2019) 63-77

Sudjana. (2001). Participatory Learning Methods \& Techniques. Bandung:Falah Production.

Sugiyono. (2009). Educational Research Methods. Bandung: Alfabeta.

Sugiyono. (2010). Qualitative Quantitative Research Methods and R \& D. Bandung: CV Alfabeta.

Sugiyono. (2015). Qualitative Quantitative Research Methodsand R\&D. Bandung: Alfabeta.

Susilana, Rudi \&Riyana, Cepi. (2007). Instructional Media. Bandung: CV. Wacana Prima.

Suwignyo, Jati. (2016). Penerapan Model Pembelajaran Computer Assisted Intruction Untuk Meningkatkan Kompetensi Teknik Membuat Aplikasi Laba Rugi SMK Kristen Salatiga. Skripsi. Retrieved fromhttps://lib.unnes.ac.id/23357/1/5302411089.pdf

Tinambunan, Arnita. Guidio, L. Melda, P. (2018). Perancangan Aplikasi Rambu-rambu Lalu Lintas Untuk Anak Usia Dini Bebasis Android Menggunakan CAI (Computer Assisted Intruction). Jurnal Riset, 5(3). Retrieved from https://ejurnal.stmikbudidarma.ac.id/index.php/jurikom/article/view/843/728

Tresnanto, Edo. (2017). Pengembangan Media Cai Super-t Bebasis Aplikasi Android Materi Satuan Ukur Mata Pelajaran Matematika Kelas IV SD. Jurnal Penelitoan Pendidikan Guru Sekolah Dasar (JPGSD).Retrieved from https://www.neliti.com/id/publications/254389/pengembangan-media-cai-super-t-berbasisaplikasi-android-materi-satuan-ukur-mata 